\title{
Integrasi Pengembangan Kreativitas Anak Usia Dini di TK Kanisius Sorowajan Yogyakarta
}

\author{
Ria Astuti ${ }^{1 凶}$, Thorik Aziz \\ ${ }^{1}$ Program Studi Pendidikan Islam Anak Usia Dini IAIN Madura \\ ${ }^{2}$ Program Studi Pendidikan Islam Anak Usia Dini UIN Sunan Kalijaga Yogyakarta
}

\begin{abstract}
Creativity is the ability to think of something in a new and unusual way then give a unique solution to the problem around us. The role of creativity is increasingly considered very important in the $21^{\text {st }}$ century marked by very fast changes and increasingly complex challenges. So that creativity must be developed early through learning conducted in an integrated manner. This research method is descriptive qualitative with the data source from a classroom teachers and the principal of TK Kanisius Sorowajan on $8^{\text {th }}$ of September 2018. The data collecting procedures are observation, interview and documentation. The data analysis activity included of data reduction, data display, and verification. The results showed that basically, every child was born creative. However, if given stimulus and treatement, the creativity would develop more and more. Creativity development carried out in Kanisius Sorowajan Kindergarten varies by integrating science, art, language, religion and IT learning in developing children's creativity integrally.
\end{abstract}

Keyword: Integrit; Creativity; Early Childhood Education

\begin{abstract}
Abstrak
Kreativitas adalah kemampuan untuk memikirkan sesuatu dengan cara yang baru dan tidak biasa serta melahirkan solusi yang unik terhadap masalah yang dihadapi. Peran kreativitas semakin terasa ketika memasuki abad 21 dengan ditandai oleh perubahan yang sangat cepat dan tantangan yang semakin kompleks. Sehingga kreativitas harus dikembangkan sejak dini melalui pembelajaran yang dilakukan secara terintegrasi. Metode penelitian ini adalah kualitatif deskriptif dengan sumber data guru kelas dan Kepala Sekolah di TK Kanisius Sorowajan Yogyakarta pada 08 September 2018. Teknik pengumpulan data yang penulis lakukan adalah dengan observasi, wawancara dan dokumentasi. Aktivitas dalam analisis data meliputi data reduction, data display, dan conclusion drawing/verification. Hasil penelitian menunjukkan bahwa pengembangan kreativitas yang dilakukan di TK Kanisius Sorowajan bervariasi dengan memadukan pembelajaran sains, seni, bahasa, agama dan IT dalam mengembangkan kreativitas anak yang dilakukan secara terintegratif.
\end{abstract}

Kata Kunci: Integrasi; Kreativitas; Anak Usia Dini

Copyright (c) 2019 Ria Astuti, Thorik Aziz

$\triangle$ Corresponding author:

Address : Jakarta Timur

Email : yunidwisuryani.yds@gmail.com 


\section{PENDAHULUAN}

Secara intelektual, perkembangan anak berbeda-beda, baik intelegensi, bakat, minat, kreativitas, kematangan emosi, kepribadian, kemandirian jasmani dan sosialnya. Setiap anak unik, berbeda dan memiliki kemampuan tak terbatas dalam kreatif dan produktif (Yamin \& Jamilah Sabri Sanan, 2013, p. 2). Oleh karena itu, pendidikan nasional berfungsi mengembangkan kemampuan dan membentuk watak serta peradaban bangsa yang bermartabat dalam mencerdaskan kehidupan bangsa, serta bertujuan untuk berkembangnya potensi peserta didik agar menjadi manusia yang beriman dan bertqwa, berakhlak mulia, sehat, berilmu, cakap kreatif, mandiri dan menjadi warga yang demokratis dan bertanggung (Martinis Yamin \& Maisah, 2012, p. 24).

Kreativitas merupakan kemampuan yang dimiliki seseorang untuk menemukan dan menciptakan suatu hal baru, cara-cara baru, atau model baru yang berguna bagi dirinya dan masyarakat. Hal baru tersebut tidak harus sesuatu yang sama sekali belum pernah ada sebelumnya, namun unsurunsurnya mungkin telah ada sebelumnya. Seseorang dapat menemukan kombinasi baru yang memiliki kualitas yang berbeda sebelumnya (Barkah Lestari, 2006, p. 18). Senada dengan pernyataan diatas kreativitas adalah kemampuan yang terdiri dari empat karakteristik yaitu kelancaran, fleksibilitas, orisinalitas, dan elaborasi.(Asmawati, 2017)

Sedangkan Deberu \& Wijayaningsih mendefinisikan kreativitas merupakan suatu kemampuan yang dimiliki oleh seseorang dalam menciptakan suatu karya yang didapatkan dari berbagai macam ide, gagasan, dan imajinasi orang itu sendiri.(Debeturu \& Wijayaningsih, 2019)

Kreativitas bukan merupakan hal yang asing bagi pembelajaran anak di TK ataupun PAUD karena setiap hal yang di kerjakan oleh anak di TK maupun PAUD merupakan kreativitas anak secara alami. (Susanti, 2016). Kegunaan kreativitas bagi anak sebagaimana dikemukakan oleh Erina Dwirahman, bahwa kreativitas berguna membekali anak semenjak usia prasekolah dengan berbagai pengalaman dan pengetahuan melalui sebuah proses kreatif, sehingga mampu mencapai masa depan dan pendidikan yang lebih baik.(Dwirahman, 2013)

Peran kreativitas semakin terasa dan merupakan keniscayaan tatkala kita memasuki abad 21, yang antara lain ditandai oleh perubahan yang sangat cepat dan tantangan yang semakin kompleks. Kreativitas dimiliki semua individu walaupun dengan derajat yang berbedabeda, dapat dipelajari, dimanipulasi dengan sengaja, dan perlu dikembangkan. Hal ini berarti semua orang dapat menjadi kreatif jika dikembangkan dengan cara-cara yang benar. Terkait dengan hal tersebut Parnes seorang tokoh besar terkemuka kreativitas, menyatakan:

“... that creativity is a behavior or set of behaviors that can be learned. Creativity is not an inborn, fixed characteristic, but is present to varying degrees in all individuals. It can be deliberately manipulated, and cultived. ... all person can become more creative, and they can apply this creativity in all facets of their lives (Masnipal, 2013, pp. 222-223).

Dalam kutipan tersebut, Parnes menyatakan bahwa kreativitas bukan potensi yang dibawa sejak lahir (not an Born). Artinya bahwa kreativitas bukan semata-mata dari individu tetapi individu dan lingkungan. Namun, pada dasarnya manusia mempunyai potensi kreatif sejak awal ia diciptakan. Potensi kreatif ini dapat kita lihat melalui keajaiban alamiah seorang bayi dalam mengeksplorasi apapun yang ada di sekitarnya. Akan tetapi, terkadang 
anak yang kreatif tidak mendapatkan fasilitas akibat orang tuanya tidak mampu sehingga dia tidak bisa mengaktualisasikan dirinya. Namun, anak yang kreatif bisa menggunakan sarana seadanya yang ada di rumah maupun di sekolah untuk berkreasi.

Dalam proses pengembangannya, Kreativitas harus dikembangkan sedini mungkin karena anak yang kreatif akan menjadi manusia dewasa yang kreatif yang mampu memecahkan berbagai permasalahan kehidupan.(Kusumawardani, 2015) Pembentukan prindividu yang kreatif yang dapat berpikir secara bebas dimungkinkan ketika guru-guru kreatif menerpkan program-program kreativitas. (Yildirim, 2010) Disamping itu peran orang tua sangat dibutuhkan namun tetap harus disesuaikan dengan kebutuhan anak "creativity or parent involvement are considerably different from each other and require specialization in those areas" (Akdağ \& Haser, 2010)

Kreativitas dapat dikembangkan dengan berbagai media, salah satunya dengan media komputer. Media komputer, anak secara aktif melakukan kegiatan bermain eksplorasi dan eksperimentasi dengan menggunakan imajinasi dan kreativitasnya dengan memanfaatkan segala pengalaman masa lalu yang telah dimilikinya.(Parwoto, 2017)

Berdasarkan realita tersebut, maka pendidikanlah yang mengemban tugas untuk dapat mengembangkan potensi kreatif yang dimiliki manusia tersebut. Dengan potensi kreativitas alami yang dimilikinya, maka anak akan senantiasa membutuhkan aktivitas yang syarat dengan ide-ide kreatif. Mereka perlu mendapatkan pembinaan yang tepat yang memungkinkan mereka untuk mengembangkan potensi dan kemampuannya itu secara optimal, yang pada akhirnya diharapkan kemampuannya tersebut dapat berguna bagi dirinya, keluarga, dan masyarakat pada umumnya.
Salah satu konsep penting dalam bidang kreativitas adalah hubungan antara kreativitas dan aktualisasi diri. Maslow membedakan antara kreativitas aktualisasi diri dan kreativitas talenta khusus. Orangorang dengan talenta khusus memiliki bakat atau talenta kreatif yang luar biasa dalam bidang seni, sastra, musik, teater, sains, bisnis atau bidang lainnya. Orang-orang ini bisa saja menunjukkan penyesuaian diri dan aktualisasi diri yang baik tetapi mungkin juga tidak. Pada umumnya orang-orang kreatif yang mengaktualisasikan dirinya adalah sehat mental, hidup sepenuhnya dan produktif, cenderung menghadapi semua aspek kehidupannya secara satu bidang khusus seperti seni atau sains (Utami Munandar, 1999, p. 24).

Dari pemaparan teori tersebut penulis menyimpulkan bahwa orang-orang kreatif dengan talenta khusus itu belum tentu dapat mengaktualisasikan dirinya. Sebaliknya, pada umumnya orang-orang kreatif yang dapat mengaktualisasikan dirinya cenderung lebih fleksibel dalam aspek kehidupannya dan produktif, namun belum tentu mempunyai bakat yang luar biasa seperti seni dan sains.

Anak yang kreatif paling tidak mempunyai tiga ciri, yaitu: originality, mempunyai pemikiran yang asli atau original. Flexibility (keluwesan), yaitu kemampuan untuk menghasilkan berbagai macam ide guna memecahkan suatu masalah di luar katagori yang biasa (Yeni Rahmawati \& Euis Kurniati, 2012, p. 14). an menunjukkan kelancaran proses berfikir (Fluency). Dengan tiga ciri utama ini, anak akan mampu menghasilkan sesuatu yang tidak sederhana dan berbeda dari peserta didik (Suharsimi Arikunto, 1980, p. 78). Adapun indikator kreatif pada anak usia dini menurut Yuliana Nurani Sujiono dan Bambang Sujinono (2010) ada 12 (dua belas) indikator, yaitu sebagai berikut: (1) Anak berkeinginan untuk mengambil resiko 
berperilaku berbeda dan mencoba hal-hal yang baru dan sulit. (2) Anak memiliki selera humor yang luar biasa dalam situasi keseharian. (3) Anak berpendirian tegas/ tetap, terang-terangan, dan berkeinginan untuk berbicara secara terbuka serta bebas.

(4) Anak adalah nonkonfermis, yaitu melakukan hal-hal dengan caranya sendiri. (5) Anak mengekspresikan secara verbal, contoh: membuat kata-kata lucu atau cerita fantastis. (6) Anak tertarik pada berbagai hal, memiliki rasa ingin tahu, dan senang bertanya. (7) Anak menjadi terarah sendiri dan termotivasi sendiri, anak memiliki imajinasi dan menyukai fantasi. (8) Anak terlibat dalam eksplorasi yang sistematis dan yang disengaja dalam membuat rencana dari suatu kegiatan. (9) Anak menyukai untuk menggunakan imajinasinya dalam bermain terutama dalam bermian pura-pura. (10) Anak menjadi inovatif, penemu, dan memiliki banyak sumber daya. (11) Anak bereksplorasi, bereksperimen dengan objek, contoh: memasukkan atau menjadikan sesuatu sebagai bagian dari tujuan. (12) Anak bersifat fleksibel dan anak berbakat dalam mendesain sesuatu.

Mengingat kreativitas ini sangat penting dikembangkan sejak dini, maka guru di TK Kanisius Sorowajan Yogyakarta selalu mengembangkan kreativitas anak dalam setiap pembelajaran. Hal ini sesuai dengan Pedoman Stimulasi Kognitif pada Anak Berbasis Kecerdasan Majemuk bahwa Kreativitas perlu dipupuk sejak dini karena merupakan proses aktualisasi diri yang dapat memberi kepuasan dan meningkatkan kualitas hidup. Untuk berkreasi, tidak selalu diperlukan alat dan benda-benda mahal. Pemanfaatan kearifan, sumber daya dan potensi lokal akan lebih bermanfaat.(Menkes, 2015)

Pengembangan kreativitas yang dilakukan di TK ini bervariatif, bahkan satu hari banyak kreativitas yang dapat dikembangkan dengan berbagai metode pembelajaran yang dilakukan secara integratif. Pemilihan TK Kanisius Sorowajan ini dikarenakan pengelolaan sekolah ini berwawasan lingkungan Holistik. Selain itu, TK Kanisius Sorowajan terpilih menjadi sekolah model berbasis IT oleh Kementrian Komunikasi dan Informatika RI melalui DIKPORA Provinsi DIY. Berdasarkan observasi yang penulis lakukan di TK ini dapat diketahui bahwa TK ini juga memanfaatkan Teknologi Informatika dalam pengembangan kreativitas anak usia dini. Tujuan penelitian ini adalah mendeskripsikan tentang pengembangan kreativitas yang dilakukan integratif di TK Kanisius Sorowajan Yogyakarta.

\section{METODOLOGI}

Penelitian ini merupakan penelitian kualitatif deskriptif. Sehingga Peneliti mengkaji satu persatu data yang didapat dari TK Kanisius Sorowajan Yogyakarta yang kemudian mendeskripsikan data tersebut secara sinergis sesuai di lapangan, serta tetap berkesinambungan berdasarkan proses penelitian yang peneliti lakukan di TK tersebut. Subjek penelitian ini diarahkan kepada pihak-pihak yang terkait dan kompeten dalam proses penyelenggaraan pendidikan di TK Kanisius Sorowajan Yogyakarta. Adapun sumber data peneliti, yaitu: guru kelas dan Kepala Sekolah di TK Kanisius Sorowajan Yogyakarta pada 08 September 2018. Ada beberapa teknik pengumpulan data yang penulis lakukan dalam penelitian ini, yakni: Observasi yang dilakukan secara terstruktur, wawancara semi-terstruktur dengan menggunakan schedule questioner atau interview guide, serta dokumentasi berbentuk gambar berupa foto kegiatan pembelajaran di TK Kanisius Sorowajan Yogyakarta. Dalam menganalisis data, peneliti menggunakan model Miles dan Huberman selama berada 
di lapangan. Aktivitas dalam analisis data meliputi data reduction, data display, dan conclusion drawing/verification.

\section{HASIL DAN PEMBAHASAN}

Penelitian ini dilakukan pada hari Sabtu, biasanya guru-guru di TK Kanisius Sorowajan Yogyakarta mengintegrasikan berbagai ilmu, salah satunya pengembangan kreativitas anak usia dini. Pengembangan kreativitas yang dilakukan di TK ini bervariasi, namun anak lebih banyak melakukan kegiatan pembelajaran dibandingkan hanya diberikan teori saja. Anak banyak melakukan berbagai percobaan yang dapat menumbuhkembangkan kreativitas mereka.

Banyak hal yang dapat diketahui dari pengamatan di TK tersebut. Ketika anakanak akan mempelajari sesuatu lebih banyak kepada praktek. Misalnya, dalam pembelajaran tema tumbuhan dengan sub tema pepaya. Pada materi ini, guru bertanya kepada anak didik "apakah sudah pernah makan pepaya?” dan jawaban dari anak didik beraneka ragam, ada yang sudah, ada yang belum, dan ada yang tidak tahu. Biasanya anak yang mengatakan tidak tahu ini adalah anak yang tidak fokus dan suka bermain.

Sebelum memulai pembelajaran tentang pepaya, guru menulis tulisan pepaya di depan papan tulis agar anak tahu tentang huruf-huruf. Guru juga mengajak anak untuk menyebutkan huruf-huruf dan cara membaca kata yang ada di papan tulis. Kemudian guru menempelkan gambar pepaya tanpa biji di papan tulis. Hal ini bertujuan agar ketika buah pepaya sudah dibelah, maka anak-anak bisa tahu komponen-komponen dan warna yang ada di dalam buah pepaya tersebut. Penyampaian materi seperti ini, merupakan pengembangan kreativitas anak usia dini melalui bahasa dan imajinasi, dimana gambar yang dibuat guru di kemudian hari untuk diwarnai oleh anak-anak. Bagi anak, mewarna adalah kegiatan yang sangat disukai dan mengasyikkan. Saat anak-anak mewarna gambar, imajinasi dan kreativitas mereka berkembang. Apalagi bila mereka diberi gambar-gambar pilihan dengan penyajian yang menarik. Imajinasi dan kreativitas anak-anak akan lebih terangsang. Oleh karena itu, kegiatan mewarna sangat baik untuk perkembangan kemampuan daya cipta atau kreativitas anak (Aisyah, 2017, p. 119).

Meskipun demikian, pengembangan kreativitas yang dilakukan di TK ini lebih kepada pembelajaran yang kontekstual, agar anak tidak hanya menerka-menerka atau membayangkan, namun diperlihatkan secara langsung produknya, yakni dalam tema ini adalah buah pepaya.

Materi pembelajaran tentang pepaya, dilanjutkan dengan cara guru membawa dua butir buah pepaya. Satu buah pepaya bewarna hijau, dan satu pepaya bewarna kuning. Hal ini dilakukan agar anak-anak mengetahui mana buah pepaya yang masih mentah dan mana buah pepaya yang sudah matang, Buah pepaya bewarna hijau dibelah dan dibuka oleh Sang Guru untuk dilihat apa saja yang terkandung di dalamnya. Setelah dibuka, buah tersebut terlihat ada getahnya. Anak-anak melihat getah tersebut bewarna bening yang lekat dan merasa penasaran. Lalu mereka berbondongbondong untuk melihat getah dan buah pepaya tersebut. Bahkan ada sebagian anak menjilat getah dari buah pepaya mentah dan berkata,"ih.. gag enak.. Pahit." Kegiatan pembelajaran seperti ini merupakan pengembangan kreativitas anak dengan sains, dimana anak melakukan pengamatan secara langsung.

Buah pepaya kedua yang bewarna kuning kemudian dibelah juga oleh guru. Setelah dibelah terdapat banyak biji bewarna hitam. Setiap apa yang dilakukan 
oleh guru, guru selalu bertanya kepada anak didik tentang komponen-komponen yang ada dibuah pepaya tersebut, seperti getah, biji, kulit, dan warna-warnanya.

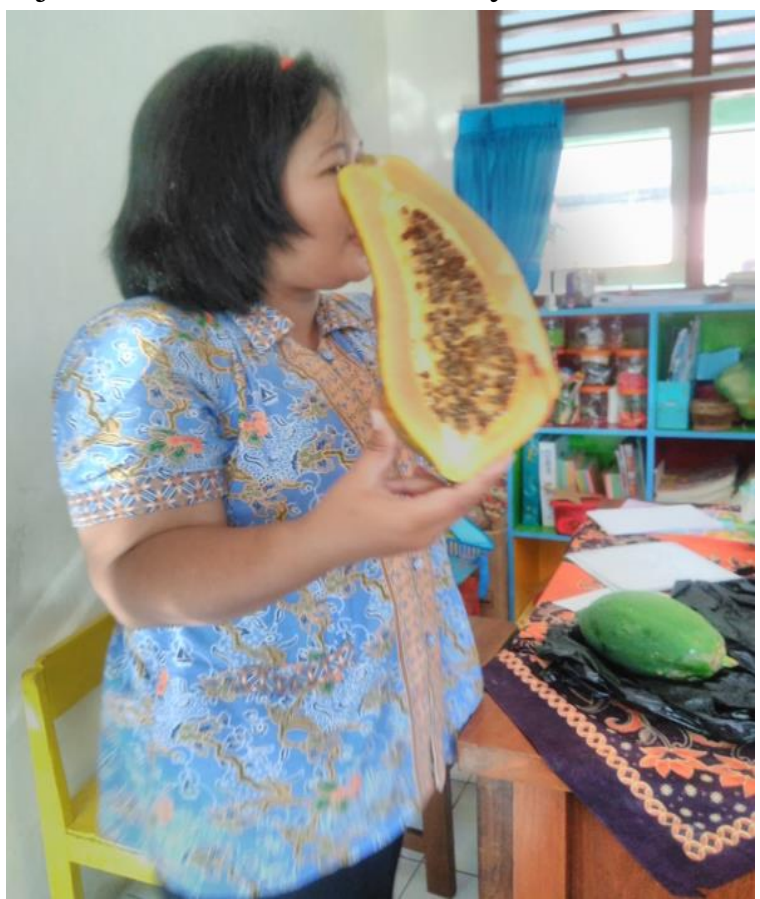

Gambar 1 Guru membelah pepaya masak dan pepaya yang mentah

Guru menjelaskan apa saja manfaat buah pepaya, dan bagaimana cara pengolahannya. Salah satu pengolahannya yang mudah dilakukan adalah dengan membuat jus pepaya. Anak-anak kembali antusias ketika melihat guru sedang memotong buah pepaya dan memasukkannya ke dalam blender. Anakanak berebutan menghidupkan dan mematikan blender, namun sang guru sangat sigap dan mengajak anak-anak antri. Hal ini sengaja dibiarkan karena biasanya di rumah mereka dilarang untuk berekperimen dengan benda-benda dapur (Ningsih: Wawancara).

Setelah menjadi jus, anak-anak diberikan masing-masing satu gelas untuk merasakan bagaimana rasanya jus pepaya. Lagi-lagi jawaban mereka bervariatif. Ada yang mengatakan enak, ada yang mengatakan tidak enak. Pembelajaran seperti ini juga dapat mengembangkan kreativitas anak melalui eksperimen.

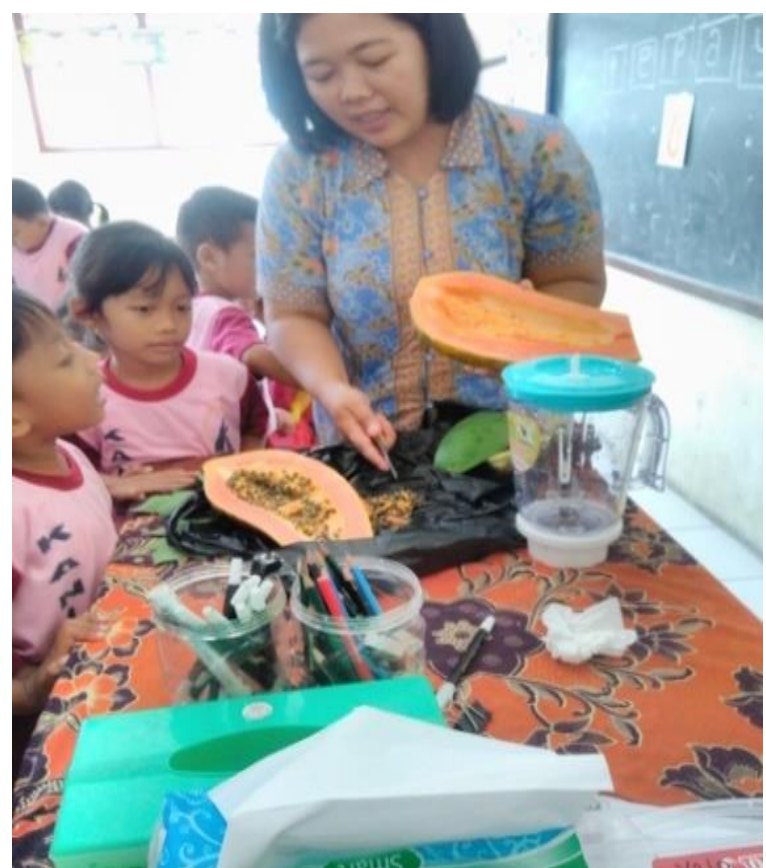

Gambar 2.

Guru menjelaskan manfaat pepaya

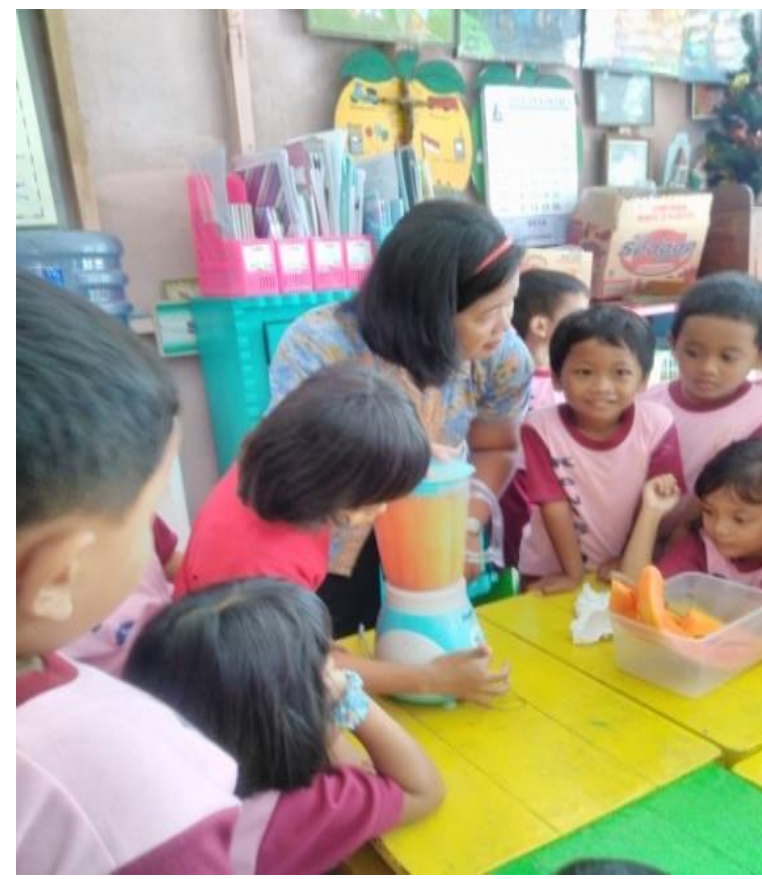

Gambar 3.

Guru mengajak anak untuk memblender pepaya

Setelah pembelajaran tentang buah pepaya selesai, anak-anak diajak ke ruang IT. Di sini anak-anak diajarkan tentang nilai-nilai agama mereka. Namun, sebelumnya mereka bernyanyi dulu dengan diiringi oleh piano. Ini merupakan pengembangan kreativitas melalui musik dan bahasa. 


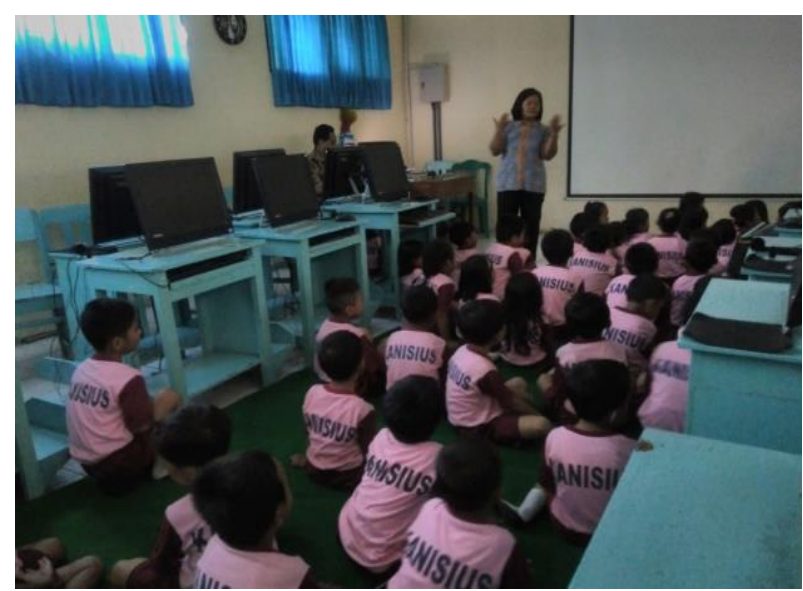

Gambar 4. Guru dan anak-anak didik bernyanyi dengan diiringi piano.

Setelah bernyanyi, guru mereka memberikan penguatan tentang nyanyian keagamaan tersebut dengan cerita yang dibawakan melalui boneka tangan. Guru berusaha mendongeng terkait nilai-nilai yang terdapat dalam lagu yang mereka nyanyikan. Cerita yang dibawakan tersebut tentang kelinci. Setelah anak memahami isi dari cerita tersebut, anak-anak diberikan tontonan tentang gabungan dari lagu yang mereka nyanyikan dan cerita yang guru sampaikan.

Selain dengan cerita, pembelajaran dengan menggunakan seni juga sangat menarik perhatian anak sehingga tidak membosankan. Salah satu kemampuan yang dikembangkan adalah kreativitas (Hasmalena \& Mahyumi Rantina, 2017, p. 82). Anak-anak antusias mendengarkan dan melihat video yang diputar oleh guru, dimana video itu sangat indah dan penuh warna. Video yang diputarkan menceritakan tentang kelinci dan dilanjutkan dengan cerita Nabi Adam dan Siti Hawa. Pembelajaran seperti ini merupakan pengembangan kreativitas melalui musik, bahasa, imajinasi, dan alat teknologi. Pengembangan kreativitas ini dilakukan secara terintegrasi oleh guru. Namun, yang memberikan pembelajaran pada ruangan ini ada tiga guru yang saling berkoordinasi satu sama yang lain.

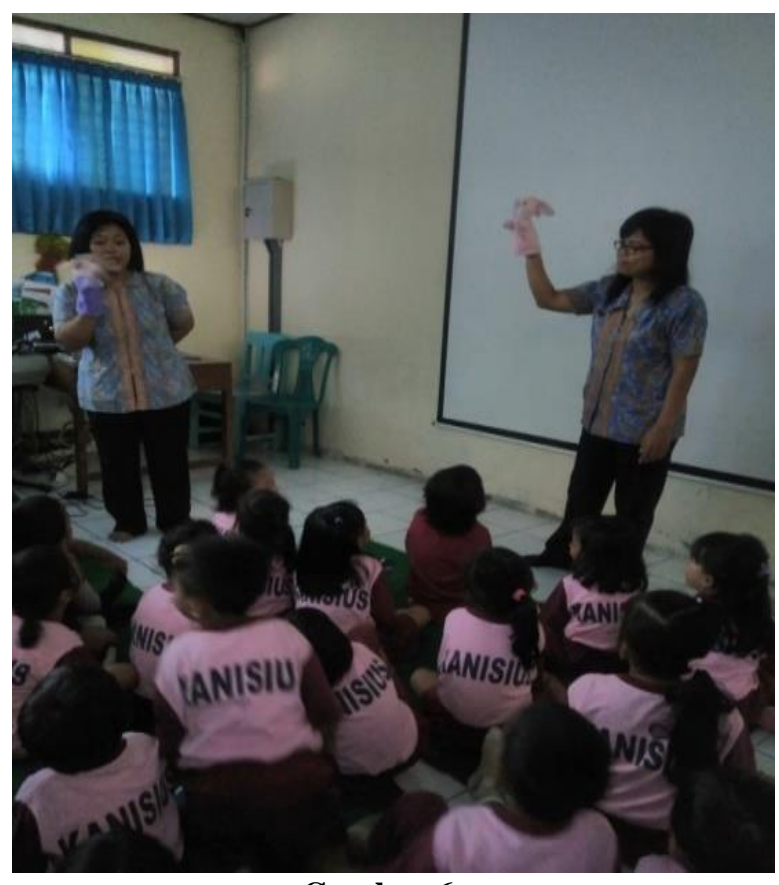

Gambar 6.

Guru mendongeng dengan boneka tangan.

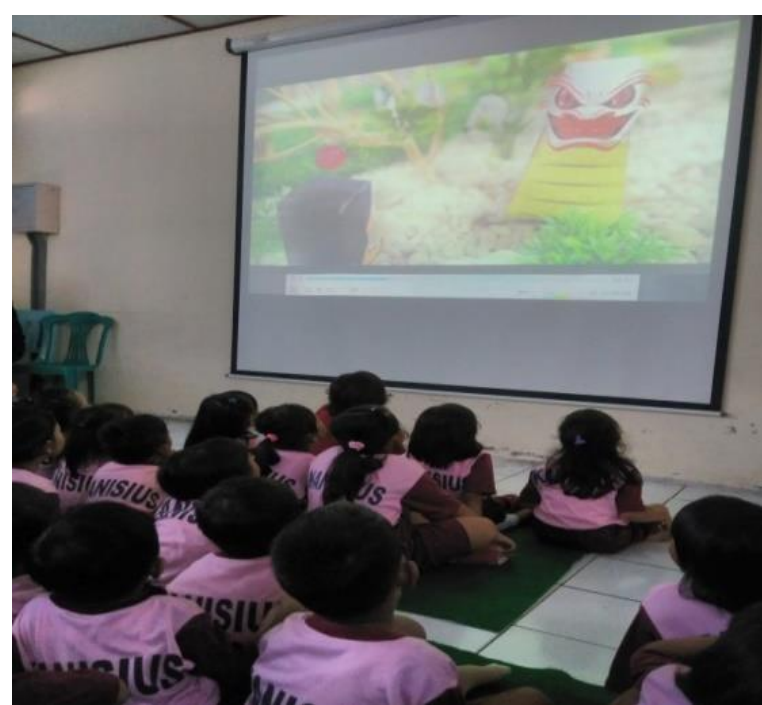

Gambar 7.

Anak-anak menonton video cerita Nabi Adam dan Siti Hawa.

Setelah pemutaran video ini, anakanak diajak kembali ke kelas. Namun, setelah anak-anak kembali ke kelas kami mewawancarai Ibu Sunarti, kepala TK Kanisius terkait pengembangan kreativitas di TK Kanisius. Ibu Sunarti mengatakan bahwa:

"Pembelajaran di TK Kanisius sangat bervariasi dan tidak terpaku dengan satu metode. Pembelajaran yang dilakukan lebih banyak melakukan praktek, hal ini dikarenakan agar anak lebih paham dan lebih ingat. Biasanya 
pembelajaran tidak hanya di dalam kelas, melainkan berada di luar kelas. Baik itu di dalam lingkungan sekolah maupun luar lingkungan sekolah. Banyak hal yang dapat dipelajari dari lingkungan sekitar anak-anak." (Sunarti: Wawancara)

Ketika ditanya tentang bagaimana mengembangkan kreativitas kepada anakanak di TK Kanisius, beliau menjawab:

"Sama halnya dengan TK-TK lainnya, di TK Kanisius juga mengembangkan kreativitas dengan berbagai metode. Adapun penggabungan dari seluruh materi pembelajaran terdapat di hari Sabtu dan disuguhkan dengan berbagai materi yang bisa mengembangkan kreativitas anak-anak. Puncak pengembangan kreativitas anak-anak biasanya dilakukan setahun sekali ketika anak akan bagi raport. Pada acara tersebut, biasanya ada anakanak yang menari, berpuisi, dan bermain peran. Selain itu, biasanya juga ada program sekolah yang melibatkan orang tua dalam membuatkan suatu kreativitas." (Sunarti: Wawancara)

Berdasarkan hasil wawancara diketahui bahwa pembelajaran yang dilakukan di TK Kanisius ini menggunakan metode bervariasi dan tidak monoton termasuk pada pengembangan kreativitas anak usia dini di TK Kanisius. Bahkan, dalam satu tema pembelajaran dapat mengembangkan kreativitas dengan banyak metode, seperti metode imajinasi, bahasa, sains dan eksperimen, serta IT. Pembelajaran bersifat kontekstual agar anak lebih paham suatu pembelajaran dengan mendalam, karena sejatinya anak usia dini belajar dari hal yang konkret ke hal yang abstrak.

Pengembangan kreativitas anak usia dini di TK Kanisius juga dikembangkan melalui pembelajaran SAINS dengan melakukan kunjungan ke beberapa tempat seperti pantai, kebun binatang atau museum sebagaimana yang diungkapkan oleh Kepala Sekolah sebagai berikut:

"Di TK Kanisius juga terdapat pembelajaran sains, dimana pembelajaran sains ini lebih banyak kepada praktek. Ketika anak-anak belajar tentang benda terapung, melayang dan tenggelam, biasanya guru langsung membawakan telur untuk dipraktekkan. Selain itu, anakanak juga biasanya setiap satu semester melakukan kunjungan ke luar lingkungan sekolah. Kunjungan tersebut bisa ke pantai, bisa ke kebun binatang, atau ke museum. Ini dilakukan agar anak mengetahui lebih banyak tentang lingkungan luar." (Sunarti: Wawancara)

Berdasarkan hasil wawancara diketahui bahwa banyak cara yang dapat dilakukan untuk mengembangkan kreativitas anak usia dini di TK Kanisius, baik itu di lingkungan sekolah, maupun di luar lingkungan sekolah. Pengembangan kreativitas dengan berkunjung ke beberapa tempat merupakan pengembangan kreativitas melalui eksplorasi lapangan. Banyak kreativitas yang dapat dikembangkan melalui kegiatan tersebut.

\section{KESIPULAN}

Pada dasarnya setiap anak terlahir sebagai anak yang kreatif. Namun, apabila diberikan stimulus dan treatementtreatment, maka kreativitas anak semakin berkembang. Pengembangan kreativitas yang dilakukan di TK ini bervariasi, namun anak lebih banyak melakukan kegiatan pembelajaran dibandingkan hanya diberikan teori saja. Anak banyak melakukan berbagai percobaan yang dapat menumbuhkembangkan kreativitas mereka. TK ini juga memadukan pembelajaran sains, seni, bahasa, dan IT dalam 
mengembangkan kreativitas anak yang dilakukan secara terintegratif.

\section{UCAPAN TERIMAKASIH}

Terimakasih kepada Kepala Yayasan TK Kanisius Sorowajan Yogyakarta yang sudah memberikan izin kepada penulis untuk melakukan penelitian di TK tersebut dan kepada pengelola Jurnal Obsesi yang berkenan menerbitkan hasil penelitian penulis yang sederhana ini.

\section{DAFTAR PUSTAKA}

Aisyah. (2017). Permainan Warna Berpengaruh Terhadap Kreativitas Anak Usia Dini. JURNAL OBSESI, Vol 1 No 2, $118-123$.

Akdağ, Z., \& Haser, Ç. (2010). Beginning early childhood education teacher's problems in Turkey. Procedia - Social and Behavioral Sciences, 9, 884-889. https://doi.org/10.1016/j.sbspro.2010.1 2.254

Asmawati, L. (2017). Peningkatan Kreativitas Anak Usia Dini melalui Pembelajaran Terpadu Berbasis Kecerdasan Jamak. JPUD - Jurnal Pendidikan Usia Dini, 11(1), 145-164. https://doi.org/10.21009/JPUD.111.10

Barkah Lestari. (2006). Upaya Orang Tua dalam Pengembangan Kreativitas Anak. Jurnal Ekonomi Dan Pendidikan, Volume $3 \mathrm{~N}$.

Debeturu, B., \& Wijayaningsih, E. L. (2019). Meningkatkan Kreativitas Anak Usia 5-6 Tahun melalui Media Magic Puffer Ball. Jurnal Obsesi : Jurnal Pendidikan Anak Usia Dini, 3(1), 233. https://doi.org/10.31004/obsesi.v3i1.1 80

Dwirahman, E. (2013). Peningkatan Kreativitas Melalui Pendekatan Inquiri dalam Pembelajaran Sains. Jurnal Pendidikan Usia Dini, 7(2), 240-250. Retrieved from http://journal.unj.ac.id/unj/index.php/j pud/article/view/3873

Hasmalena, \& Mahyumi Rantina. (2017). Impelementasi Cerita Rakyat melalui
Mata Kuliah Pendidikan Seni Tari Usia Dini untuk Meningkatkan Kreativitas Pada Mahasiswa PGPAUD FKIP UNSRI. JURNAL OBSESI, Volume $1 \mathrm{~N}, 81-85$.

Kusumawardani, R. (2015). Peningkatan Kreativitas melalui Pendekatan Brain Based Learning. Jurnal Pendidikan Usia Dini, 9(1), 143-162. https://doi.org/10.21009/JPUD.091.09

Martinis Yamin, \& Maisah. (2012). Orientasi Baru Ilmu Pendidikan. Jakarta: Refrensi.

Masnipal. (2013). Siap Menjadi Guru dan Pengelola PAUD Professional. Jakarta: PT. Gramedia.

Menkes, R. Pedoman Stimulasi Kognitif pada Anak Berbasis Kecerdasan Majemuk. , Pub. L. No. Nomor 62 Tahun 2015 (2015).

Parwoto, P. (2017). Pengaruh Penerapan Metode Pembelajaran Collaborative Problem Based Learning (CPBL) terhadap Kreativitas Anak dalam Bermain Komputer. JPUD - Jurnal Pendidikan Usia Dini, 11(1), 97-116. https://doi.org/10.21009/JPUD.111.07

Suharsimi Arikunto. (1980). Menejemen Pengajaran Secara Manusiawi. Yogyakarta: Rineka Cipta.

Susanti, R. (2016). Meningkatkan Kreativitas Anak Usia Dini Melalui Bermain Plastisin. Jurmal Audi, 1(2), 92-102.

https://doi.org/10.1017/CBO97811074 15324.004

Utami Munandar. (1999). Kreativitas dan Keberkatan (cet. Ll). Jakarta: PT Gramedia Pustaka Utama.

Yamin, M., \& Jamilah Sabri Sanan. (2013). Panduan PAUD (cet ke 1). Ciputat: Gaung Persada Press Group.

Yeni Rahmawati, \& Euis Kurniati. (2012). Strategi Pengembangan Kreativitas (cet. ke 3). Jakarta: Kencana.

Yildirim, A. (2010). Creativity in early childhood education program. Procedia - Social and Behavioral Sciences, 9, 1561-1565. https://doi.org/10.1016/j.sbspro.2010.1 2.365 